\title{
Analisis Pengaruh Earning per-share, Price earning ratio dan Price to book value Terhadap Harga Saham Perusahaan Konstruksi Milik Negara yang Terdaftar di Bursa Efek Indonesia
}

\author{
Idawanda 1, Baharuddin Semmaila², Asdar Djamereng ${ }^{3}$ \\ 1,2 Program Magister Ilmu Manajemen, Universitas Muslim Indonesia \\ ${ }^{3}$ Fakultas Ekonomi dan Bisnis, Universitas Muslim Indonesia \\ Email Korespondensi: idawanda.wanda@gmail.com
}

\begin{abstract}
Abstrak
Penelitian ini dilakukan bertujuan untuk (1) mengetahui pengaruh earning per-share terhadap harga saham, (2) mengetahui pengaruh price earning ratio terhadap harga saham, (3 mengetahui pengaruh price to book value terhadap harga saham, (4) mengetahui apakah Earning Per Share, price earning ratio, dan price to book value berpengaruh secara serempak terhadap harga saham. Penelitian ini menggunakan data sekunder melalui sumber data dan bursa efek Indonesia yang telah diterbitkan perusahaan, sebanyak 9 perusahaan dalam kurun waktu 5 tahun. Penelitian ini dilakukan dalam jangka waktu penelitian mulai bulan Agustus sampai dengan Oktober 2020. Metode: analisis yang digunakan adalah analisis regresi linier berganda, uji asumsi klasik, uji parsial, uji simultan, dan uji koefisien determinasi. Data dianalisis dengan menggunakan program software Statistical Product and Service Solution (SPSS) 23. Hasil penelitian ini menyatakan bahwa (1) Earning Per Share berpengaruh positif dan signifikan terhadap harga saham, (2) price earning ratio berpengaruh positif dan signifikan terhadap harga saham, (3) price to book value berpengaruh positif dan signifikan terhadap harga saham, (4) Earning Per Share, price earning ratio, debt to equity, price to book value berpengaruh secara serempak terhadap harga saham. Oleh karena itu, diharapkan perusahaan konstruksi meningkatkan kinerjanya agar semakin meningkatkankan harga saham.
\end{abstract}

Kata Kunci: earning per-share, price earning ratio, price to book value, harga saham.

\section{Pendahuluan}

Pada era globalisasi seperti sekarang ini persaingan di dunia usaha semakin berkembang. Semakin banyaknya perusaaan baru yang muncul yang bersaing dengan perusahaan lama. Tujuan perusahaan adalah ingin menjalankan usahanya dalam waktu yang lama. Selain itu, tujuan perusahaan adalah mencari laba besar untuk kesejahteraan karyawannya dan perusahaan itu sendiri. Persaingan yang semakin ketat, perusahaan harus melakukan segala cara untuk terus tumbuh dan berkembang, agar terus tumbuh dan berkembang tidaklah hal yang mendorong perusahaan untuk mencari sumber pembiayaan yang dapat menyediakan dana dengan jumlah yang cukup besar yang digunakan untuk mengembangan usaha, peningkatan produksi, dan kegiatan operasional perusahaan lainnya.

Keberhasilan perusahaan dapat dilihat dari laju pertumbuhan yang tinggi dimana pertumbuhan tersebut memerlukan dukungan tambahan investasi dari investor. Salah satu alternatif pilihan diambil perusahaan dalam memperoleh dana tambahan dan dengan menjual surat-surat berharga, apakah dalam bentuk saham, obligasi ataupun surat berharga lainnya. Untuk melakukan kegiatan perdagangan saham maka diperlukan pasar modal. Pasar modal merupakan pasar untuk berbagai instrumen keuangan jangka panjang yang bisa diperjual belikan, baik dalam bentuk hutang, ekuitas (saham) instrumen derivatif, maupun instrumen lainnya (Ang, 1997). Pada Undang-undang No. 8 Tahun 1995 tentang pasar modal, instrumen pasar modal adalah semua surat berharga (efek) yang paling umum diperjual belikan melalui pasar modal. Instrumen yang paling umum diperjual belikan melalui Bursa Efek Indonesia (BEI) adalah saham, obligasi, right dan warran. Manfaat pasar modal 
yang berkembang nantinya akan lebih mendorong tumbuhnya lembaga-lembaga penunjang pasar modal lainnya yang belum ada sekarang(www.sahamok.com, 2017). Bursa Efek Indonesia (BEI) merupakan sebuah pasar yang berhubungan dengan pembelian dan penjualan efek perusahaan yang sudah terdaftar di bursa. Bursa efek tersebut, bersama-sama dengan pasar uang merupakan sumber utama permodalan eksternal bagi perusahaan dan pemerintahan (Agustiningrum, 2011). Sebelum berinvestasi di saham, investor perlu melakukan analisa lebih dalam sebagai bentuk perhatian dan hati - hati dalam memutuskan ke perusahaan mana modalnya akan ditanamkan. Risiko yang menyertai investasi dapat diminimalkan oleh investor. Seorang investor perlu melakukan analisis sebagai alat untuk mengambil keputusan investasi, memahami seluk beluk bursa dan memprediksi tren saham maupun pergerakan harga saham yang selalu berubah. Oleh karena itu, investor cukup memilih metode yang mampu dipahami dan diterapkan dalam memprediksi nilai yang terkandung dalam saham yang akan dibelinya (Kartini \& Setiawan, 2017). Terdapat dua pendekatan atau analisis yang dilakukan investor dalam menganalisis suatu harga efek khususnya saham, yaitu: analisis fundamental dan analisis teknikal. Analisis fundamental berasal dari faktor internal perusahaan (struktur modal, risiko dan pertumbuhan laba, pembagian dividen, kondisi perusahaan yang dapat dilihat dari laporan keuangan perusahaan atau emiten) dan faktor eksternal (kebijakan pemerintah, kondisi ekonomi, dan sentimen pasar). Analisis teknikal menganalisis perilaku pasar melalui pergerakan harga dimasa lalu untuk memprediksikan harga dimasa yang akan datang yang tercermin dalam grafik dengan berbagai indikator teknikal (Abdullah et al., 2017). Rasio pasar merupakan sekumpulan rasio yang menghubungkan harga saham dengan laba dan nilai buku per saham. Rasio ini memberikan petunjuk mengenai apa yang dipikirkan investor atas kinerja perusahaan di masa lalu serta prospek di masa mendatang (Nasser, 2007). Rasio pasar yang digunakan adalah Earning Per Share (EPS), Price earning ratio (PER) dan rasio yang mempengaruhi return saham yaitu nilai buku per lembar saham atau Price to book value (PBV). Market Book atau Price to book value merupakan rasio pasar yang digunakan untuk mengukur kinerja harga pasar saham terhadap nilai buku suatu saham. Perusahaan dikatakan dapat beroperasi dengan baik jika memiliki rasio Price to book value di atas satu (Starovic \& Marr, 2003). Price to book value (PBV) merupakan suatu nilai yang dapat digunakan untuk membandingkan apakah sebuah saham lebih mahal atau lebih murah dibandingkan dengan saham lainnya. Untuk membandingkannya, kedua perusahaan harus dari satu kelompok usaha yang memiliki sifat bisnis yang sama(Asna \& Graha, 2006). Rasio Price to book value menggambarkan nilai pasar keuangan terhadap manajemen dan organisasi dari perusahaan yang sedang berjalan (going concern) (Ningsih et al., 2016).

Earning Per Share merupakan komponen penting pertama yang harus diperhatikan dalam analisis perusahaan. Informasi EPS suatu perusahaan menunjukkan besarnya laba bersih perusahaan yang siap dibagikan bagi pemegang saham perusahaan. Besarnya EPS suatu perusahaan bisa diketahui dari informasi laporan keuangan (Eprima Dewi et al., 2015). Earning Per Share adalah rasio yang menunjukkan berapa besar keuntungan (return) yang diperoleh investor setiap lembar saham. EPS menunjukkan semakin besar keuntungan tiap lembar saham bagi pemilikinya, maka hal itu akan mempengaruhi return saham perusahaan di pasar modal. Laba per lembar saham adalah jumlah pendapatan yang diperoleh dalam satu periode untuk tiap lembar saham yang beredar dan akan dipakai oleh pimpinan perusahaan untuk menentukan besarnya dividen yang akan dibagikan (10). PER menunjukkan besarnya harga setiap satu rupiah earning perusahaan. Di samping itu, PER juga merupakan ukuran harga relatif sebuah saham perusahaan (Eprima Dewi et al., 2015). Rasio PER mencerminkan pertumbuhan laba perusahaan. Semakin tinggi rasio ini, semakin tinggi pertumbuhan laba yang diharapkan oleh pemodal. Price earning ratio (PER) membandingkan antara harga saham (yang diperoleh dari pasar modal) dan laba per lembar saham yang diperoleh pemilik perusahaan (disajikan dalam laporan keuangan) (W.Wahyuni, 2012). PER merupakan bagian dari rasio pasar, di mana sudut pandang rasio pasar ini lebih banyak berdasarkan pada sudut investor atau calon investor. Keinginan investor melakukan analisis kesehatan suatu saham melalui rasio-rasio keuangan seperti PER, dikarenakan adanya keinginan investor dan calon investor akan hasil (return) yang layak atas suatu investasi saham (Hery, 2016). Price earning ratio (PER) merupakan rasio yang menunjukkan seberapa banyak investor bersedia membayar tiap lembar saham (Tangngisalu et al., 2020). Price earning ratio menghubungkan antara harga pasar per lembar saham dengan Earning Per Share saham yang bersangkutan. PER merupakan ekspektasi dari nilai saham pada masa yang akan datang, sehingga suatu saham dari perusahaan dengan kinerja dan prospek usaha yang menguntungkan akan 
memiliki nilai PER yang tinggi. Sebaliknya saham perusahaan yang tidak memiliki kinerja dan prospek usaha yang menguntungkan akan memiliki nilai PER yang rendah. Investor mempertimbangkan rasio tersebut guna memilah-milah saham mana mana yang nantinya memberikan keuntungan yang besar di masa yang akan datang dan pertimbangannya jika perusahaan mempunyai PER yang terlalu tinggi tidak akan menarik karena harga saham kemungkinan tidak naik lagi berarti kemungkinan memperoleh capital gain akan lebih kecil (12). Price earning ratio menjadi tidak mempunyai makna apabila perusahaan mempunyai laba yang sangat rendah (ubnormal) atau menderita kerugian. Ada keadaan ini, PER perusahaan akan begitu tinggi (abnormal) atau bahkan negatif (Priastuti \& Lestariningsih, 2016). Penelitian lain yang berkaitan dengan faktor-faktor yang mempengaruhi return saham antara lain penelitian yang meneliti analisis pengaruh Book Value (BV), Current Ratio (CR), Earning Per Share (EPS), Price Book Value (PBV), Price earning ratio (PER) dan Total Asset Turn Over (TATO) terhadap harga saham (studi kasus pada perusahaan Go Publik yang terdaftar di BEI periode 2014-2017). Hasilnya menunjukkan Earning Per Share dan Price to Value Book mempunyai pengaruh yang signifikan terhadap harga saham sedangkan Price earning ratio tidak berpengaruh secara signifikan terhadap harga saham.

Berdasarkan latar belakang di atas, dapat disimpulkan masih terjadi hasil yang berbeda-beda dari beberapa faktor yang mempengaruhi harga saham, dan berdasarkan hal tersebut penulis ingin meneliti kembali tentang variabel yang mempengaruhi harga saham melalui penelitian yang berjudul "Pengaruh Earning Per Share, Price earning ratio dan Price to book value Terhadap Harga Saham Perusahaan Konstruksi Milik Negara yang Terdaftar di Bursa Efek Indonesia (BEI).

\section{Metode Penelitian}

Penelitian ini merupakan penelitian asosiatif yaitu peneltiian yang bertujuan untuk mengetahui pengaruh ataupun juga hubungan antara dua variabel atau lebih (Firman \& Putra, 2020). Data dalam penelitian ini bersumber dari laporan keuangan yang berasal dari Indonesian Capial Market Directory (ICMD) dan IDX Statistics. Metode penelitian ini menggunakan analisis regresi berganda. Analisis ini digunakan untuk mengukur kekuatan dua variabel atau lebih dan juga menunjukkan arah hubungan antara variabel dependen dengan variabel independen. Adapun rumus dari regresi linier berganda (multiple linier regression) adalah sebagai berikut :

$$
\mathrm{Y}=\mathrm{a}+\mathrm{b} 1 \mathrm{X1}+\mathrm{b} 2 \mathrm{X} 2+\mathrm{b} 3 \mathrm{X} 3+\mathrm{e}
$$

Keterangan :

$\mathrm{Y}=$ Return saham

$\mathrm{X} 1=$ Earning Per Share

$\mathrm{X} 2=$ Price earning rasio

$\mathrm{X} 3=$ Price to book value

$\mathrm{a}=$ Konstanta

b1 = Koefisien regresi variabel Earning Per Share

b2 = Koefisien regresi variabel price earning ratio

b3 = Koefisien regresi variabel price to book value

$\mathrm{e}=$ Faktor kesalahan

Populasi dalam penelitian ini adalah seluruh perusahaan konstruksi yang sudah terdaftar dan masih terdaftar di Bursa Efek Indonesia (BEI) periode 2014-2018 berjumlah 106 perusahaan. Sampel dalam penelitian ini ada 9 perusahaan yang termasuk dalam perusahaan konstruksi milik Negara. Dengan rentan waktu 5 tahun. Berikut 9 perusahaan konstruksi milik Negara :

Tabel 1. Daftar Nama Perusahaan

\begin{tabular}{|c|c|l|}
\hline No. & Kode Saham & \multicolumn{1}{|c|}{ Nama Emiten } \\
\hline 1. & ACST & Acset Indonusa Tbk \\
\hline 2. & ADHI & Adhi Karya (Persero) Tbk \\
\hline 3. & DGIK & Nusa Konstruksi Enjiniring TBK d.h Duta Graha Indah Tbk \\
\hline 4. & NRCA & Nusa Raya Cipta Tbk \\
\hline 5. & PTPP & Pembangunan Perumahan (Persero) Tbk \\
\hline 6. & SSIA & Surya Semesta Internusa Tbk \\
\hline
\end{tabular}




\begin{tabular}{|c|c|l|}
\hline 7. & TOTL & Total bangun Persada Tbk \\
\hline 8. & WIKA & Wijaya Karya (Persero) Tbk \\
\hline 9. & WKST & Waskita Karya (Persero) Tbk \\
\hline
\end{tabular}

Variabel bebas terdiri atas Earning Per Share (X1), Price earning ratio (X2) dan Price to book value (X3). Variabel terikat yaitu Harga Saham (Y). Data ini dianalisis dengan menggunakan SPSS 23.0

\section{Hasil Penelitian dan Pembahasan}

Pengujian ini dilakukan untuk mengukur seberapa besar pengaruh dari variabel bebas yakni Earning Per Share, price earning ratio, price to book value terhadap variabel terikat yakni harga saham (Y). Hasil uji regresi linear berganda dapat dilihat pada tabel 2 berikut:

Tabel 2. Hasil Analisa Regresi Berganda

\begin{tabular}{|c|c|c|c|c|c|c|}
\hline \multirow{2}{*}{\multicolumn{2}{|c|}{ Model }} & \multicolumn{2}{|c|}{ Unstandardized Coefficients } & $\begin{array}{l}\text { Standardized } \\
\text { Coefficients }\end{array}$ & \multirow[b]{2}{*}{$\mathrm{t}$} & \multirow[b]{2}{*}{ Sig. } \\
\hline & & $\mathrm{B}$ & Std. Error & Beta & & \\
\hline \multirow[t]{4}{*}{1} & (Constant) & $-113,260$ & 198,020 & &,- 572 &, 570 \\
\hline & EPS & 6,085 & 1,107 &, 512 & 5,495 & 000 \\
\hline & PER & 18,825 & 6,995 & 277 & 2,691 & 010 \\
\hline & PBV & 445,158 & 107,742 & ,426 & 4,132 &, 000 \\
\hline
\end{tabular}

$$
\begin{aligned}
& Y=a+b 1 X 1+b 2 X 2+b 3 X 3+e \\
& Y=-113,260+6,085 X 1+18,825 X 2+445,158 X 3
\end{aligned}
$$

Hasil regresi berganda di atas menunjukkan variabel bebas yakni Earning Per Share, price earning ratio, dan price to book value berpengaruh positif dan signifikan terhadap variabel terikat yaitu harga saham. Di mana setiap kenaikan yang terjadi pada variabel bebas akan diikuti pula oleh kenaikan variabel terikat. Selain itu dari hasil tersebut dapat dilihat bahwa variabel bebas yang paling dominan berpengaruh terhadap harga saham adalah variabel price to book value dengan hasil regresi paling besar di antara variabel yang lain yaitu 445,158 dan besarnya pengaruh price to book value terhadap harga saham adalah 0,426 atau $42,6 \%$.

\section{Uji t (Parsial)}

Pengujian ini untuk melihat sejauh mana pengaruh secara parsial variabel bebas $(X)$ terhadap variabel terikat $(\mathrm{Y})$ berdasarkan hasil regresi. Uji t dilakukan dengan membandingkan nilai $t$ hitung dengan nilai $\mathrm{t}$ tabel dengan tingkat kepercayaan 5\% yakni 2,019. Apabila $\mathrm{t}$ hitung $>\mathrm{t}$ tabel maka dapat disimpulkan variabel tersebut mempunyai pengaruh yang signifikan.

1. Variabel Earning Per Share. Nilai t hitung untuk variabel ini sebesar 5,495. Sementara itu nilai pada tabel distribusi 5\% sebesar 2,019 maka $t$ hitung $(5,495)>t$ tabel $(2,019)$. Hal ini berarti variabel Earning Per Share mempunyai pengaruh signifikan terhadap harga saham dan setiap kenaikan satu satuan Earning Per Share maka terjadi peningkatan sebesar 5,495. Taraf signifikan hasil perhitungan lebih kecil dari taraf signifikansi, $0,000<0,05$ artinya hipotesis diterima, besarnya pengaruh Earning Per Share terhadap harga saham adalah 0,512 atau 51,2\%.

2. Variabel price earning ratio. Nilai thitung untuk variabel ini sebesar 2,691. Sementara itu, nilai pada tabel distribusi 5\% sebesar 2,019 maka t hitung $(2,691)>(2,019)$. Hal ini berarti price earning ratio mempunyai pengaruh dan signifikan terhadap harga saham. Dikarenakan taraf signifikan hasil perhitungan lebih kecil dari taraf signifikansi. 0,010<0,05 itu artinya hipotesis diterima, besarnya pengaruh price earning ratio terhadap harga saham adalah 0,277 atau $27,7 \%$ dan setiap naik satu satuan price earning ratio pada batasan tertentu maka terjadi peningkatan saham sebesar 2,691.

3. Variabel price to book value. Nilai t hitung untuk variabel ini sebesar. Sementara itu nilai pada tabel distribusi $5 \%$ sebesar 2,019. Maka t hitung $(4,132)>(2,019)$. Hal ini berarti variabel price 
to book value mempunyai pengaruh positif dan signifikan terhadap harga saham saham. Setiap kenaikan satu satuan price to book value maka terjadi peningkatan harga saham sebesar 4,132. Taraf signifikan hasil perhitungan lebih kecil dari taraf signifikansi, 0,000 < 0,05 itu artinya hipotesis diterima. Besarnya pengaruh price to book value terhadap harga saham adalah 0,426 atau $42,6 \%$. Berdasarkan hasil uji $t$ di atas maka dapat disimpulkan bahwa variabel Earning Per Share, price earning ratio dan price to book value berpengaruh secara signifikan terhadap harga saham. Variabel paling dominan mempengaruhi harga saham adalah Earning Per Share dengan nilai t hitung yang paling besar (5,495), dengan signifikan sebesar 0,000 . Dan pengaruhnya sebesar $51,2 \%$.

2. Pengaruh Earning Per Share terhadap harga saham

Hasil uji secara parsial (uji-t) variabel Earning Per Share menunjukkan nilai $t$ hitung $<\mathrm{t}$ tabel $(5,495<2,019)$ dan nilai signifikansi di bawah 0,05 $(0,000<0,05)$ yang berarti terdapat pengaruh signifikan antara variabel Earning Per Share terhadap harga saham. Hal ini berarti variabel Earning Per Share mempunyai pengaruh signifikan terhadap harga saham dengan tingkat signifikansi 0,000 sehingga dihasilkan kesimpulan yang mendukung teori dan berbagai penelitian sebelumnya. Kenaikan 1\% Earning Per Share meningkatkan harga saham sebanyak 0,512.Dengan meningkatnya laba bersih setelah pajak yang dihasilkan oleh perusahaan, maka harga yang akan diterima oleh para pemegang saham juga semakin meningkat. Berdasarkan hasil uraian di atas maka Earning Per Share dapat digunakan dalam memprediksi tentang harga saham. Sehubungan dengan hal tersebut nampak bahwa investor dalam memprediksi harga saham juga memperhatikan kinerja saham dari sisi rasio pasarnya terumata Earning Per Share dari saham perusahaan (emiten). Penelitian ini sesuai dengan hasil penelitian yang mengemukakan bahwa Earning Per Share (EPS) merupakan rasio yang menunjukkan bagian laba untuk setiap lembar saham. Makin tinggi nilai Earning Per Share (EPS) tentu saja menggembirkan pemegang saham karena makin besar laba yang disediakan untuk pemegang saham, dengan demikian harga saham yang akan diterima investor juga makin besar. Peneliti yang lain juga mengemukakan dalam penelitiannya bahwa Earning Per Share memberikan pengaruh positif terhadap harga saham (Dharmastuti \& Wirjolukito, 2004).

\section{Pengaruh Price earning ratio terhadap harga saham}

Dari hasil perhitungan uji parsial diperoleh nilai t hitung sebesar $(2,691>2,019)$ dengan nilai signifikansi 0,010. Karena nilai signifikansi lebih kecil dari 0,05 maka hipotesis diterima berarti ada pengaruh signifikan yang positif antara variabel price earning ratio terhadap variabel harga saham. Pengaruh positif artinya ketika price earning ratio naik satu satuan pada batasan tertentu maka harga saham meningkat sebesar 0,277. Hasil penelitian ini sesuai dengan hasil penelitian yang menghasilkan price earning ratio berpengaruh positif terhadap harga saham (Cao et al., 2003) (Kartini \& Setiawan, 2017). Namun, berbanding terbalik dengan penelitian yang menyimpulkan price earning ratio tidak berpengaruh positif terhadap harga saham (Prasetyorini, 2013).

\section{Pengaruh Price to book value terhadap harga saham}

Dari hasil perhitungan uji secara parsial diperoleh nilai $t$ hitung sebesar $(4,132)$ dengan nilai signifikansi sebesar 0,000. Karena nilai signifikansi lebih kecil dari 0,05 maka hipotesis diterima. Berarti ada pengaruh signifikan antara price to book value terhadap variabel harga saham. Berpengaruh positif artinya setiap kenaikan saru satu price to book value maka terjadi peningkatan sebesar $42,6 \%$. Hal ini yang sangat penting untuk diperhatikan oleh manajer karena price to book value mampu meningkatkan harga saham perusahaan konstruksi sehingga mendatangkan calon investor. Hasil penelitian ini sesuai dengan penelitian yang menyimpulkan ada pengaruh positif dan signifikan antara price to book value dengan harga saham (Fitriyani, 2016).

\section{Simpulan dan Saran}

Berdasarkan hasil analisis dan pembahasan yang telah dijelaskan di bab sebelumnya, dapat disimpulkan sebagai berikut:

a) Terdapat pengaruh positif dan signifikan Earning Per Share (EPS) terhadap harga saham pada perusahaan konstruksi yang terdaftar di BEI periode 2014-2018. Earning Per Share atau laba per 
lembar saham merupakan kemampuan perusahaan untuk menghasilkan keuntungan per lembar saham pemilik. Semakin besar nilai Earning Per Share tentu akan semakin menguntungkan bagi pemegang saham karena semakin besar juga keuntungan yang disediakan oleh perusahaan untu pemegang saham. Sehingga dapat disimpulkan bahwa hipotesis 1 terbukti.

b) Terdapat pengaruh positif dan signifikan Price earning ratio (PER) terhadap harga saham pada perusahaan konstruksi yang terdaftar di BEI periode 2014-2018. Hal ini berarti setiap kenaikan satua satuan Price earning ratio pada batasan tertentu maka tejadi peningkatan harga saham. Rasio Price earning ratio mencerminkan pertumbuhan laba perusahaan. Semakin tinggi rasio ini, semakin tinggi pertumbuhan laba yang diharapkan pemodal. Sehingga dapat disimpulkan bahwa hipotesis 2 terbukti.

c) Terdapat pengaruh positif dan signifikan Price to book value (PBV) terhadap harga saham pada perusahaan konstruksi yang terdaftar di BEI periode 2014-2018. Perusahaan dikatakan beroperasi dengan baik jika memiliki rasio Price to book value di atas satu. Hal ini menunjukkan nilai pasar lebih besar daripada nilai bukunya. Semakin besar rasio Price to book value semakin tinggi perusahaan dinilai oleh para pemodal relatif dibandingkan dengan dana yang telah ditanamkan di perusahaan (7). Sehingga dapat disimpulkan bahwa hipotesis 3 terbukti.

d) Terdapat pengaruh positif dan signifikan variabel Earning Per Share (EPS), Price earning ratio (PER), dan Price to book value (PBV) secara bersama-sama (simultan) terhadap harga saham pada perusahaan konstruksi yang terdaftar di BEI periode 2014-2018. Sehingga dapat disimpulkan bahwa hipotesis 4 terbukti.

\section{DAFTAR PUSTAKA}

Abdullah, W., Syariati, A., \& Hamid, R. (2017). Pengaruh Corporate Social Responsibility (Csr), Ukuran Perusahaan Dan Interest Based Debt (Ibd) Terhadap Nilai Perusahaan Pada Perusahaan Manufaktur Di Jakarta Islamic Index Periode 2010-2016. Jurnal Minds: Manajemen Ide Dan Inspirasi. https://doi.org/10.24252/minds.v4i2.4192

Agustiningrum, R. (2011). Analisis pengaruh CAR, NPL, dan LDR terhadap profitabilitas pada Perusahaan Perbankan. E-Jurnal Manajemen Universitas Udayana, 885-902.

Ang, R. (1997). Buku pintar pasar modal Indonesia. Mediasoft Indonesia.

Asna, \& Graha, A. N. (2006). Analisis Pengaruh Rasio Kuangan terhadap Return Saham Perbankan yang Terdaftar di Bursa Efek Indonesia. Research Gate, 2(3), 192-212.

Cao, Y., Gruca, T. S., \& Klemz, B. R. (2003). Internet Pricing, Price Satisfaction, and Customer Satisfaction. International Journal of Electronic Commerce, 8(2), 31-50. https:/ / doi.org/10.1080/10864415.2003.11044291

Dharmastuti, F., \& Wirjolukito, A. (2004). Analisis Pengaruh Faktor-Faktor Keuangan Terhada Harga Saham Perusahaan Go Pulbik di BEJ. Jurnal Manajeman, 1(1).

Eprima Dewi, L., Trisna Herawati, N. S., \& Gede Erni Sulindawati, L. S. (2015). Analisis Pengaruh NIM, BOPO, LDR, DAN NPL Terhadap Profitabilitas (Studi Kasus Pada Bank Umum Swasta Nasional Yang Terdaftar Pada Bursa Efek Indonesia Periode 2009-2013 ). E-Jurnal S1 Ak. Universitas Pendidikan Ganesha Jurusan Akuntansi Program S1, 3(1).

Firman, A., \& Putra, A. H. P. K. (2020). The Effect of Social Media Utilization, Campus Environment and Entrepreneurship Knowledge on Student Entrepreneurial Interest. Point Of View Research Management, 3(4), 131-143.

Fitriyani, V. K. (2016). Pengaruh Intellectual Capital Terhadap Nilai Perusahaan Yang Diukur Menggunakan Tobins Q Pada Saham-Saham Lq-45 Periode 2011-2015. Universitas Widyatama.

Hery. (2016). Analisis Laporan Keuangan. In Analisis Laporan Keuangan (p. 4).

Kartini, K., \& Setiawan, D. A. (2017). Faktor-Faktor Yang Mempengaruhi Perilaku Overconfidence Investor Saham Di Yogyakarta. Jurnal Riset Manajemen Sekolah Tinggi Ilmu Ekonomi Widya Wiwaha Program Magister Manajemen, 4(1), 36-46.

Nasser, E. M. (2007). Perbandingan Kinerja Bank Pemerintah dan Bank Swasta Dengan Rasio CAMEL Serta Pengaruhnya Terhadap Harga Saham. Media Riset Akuntansi, Auditing E Informasi, 3(3), 217-236.

Ningsih, E., Rambe, P. A., \& Suprihartini, L. (2016). Pengaruh Kualitas Audit, Audit Client Tenure, Debt Default, Opinion Shopping dan Kondisi Keuangan Perusahaan Terhadap Penerimaan Opini Audit Going Concern. Skripsi.

Prasetyorini, B. F. F. (2013). Pengaruh ukuran perusahaan, leverage, price earning ratio dan profitabilitas terhadap nilai perusahaan. Jurnal Ilmu Manajemen (JIM), 1(1).

Priastuti, S., \& Lestariningsih, M. (2016). Analisis Perbandingan Laporan Keuangan. 5.

Starovic, D., \& Marr, B. (2003). Understanding corporate value: managing and reporting intellectual capital. CIMA. 
Tangngisalu, J., Mappamiring, M., Andayani, W., Putra, M. Y., \& Kusuma, A. H. P. (2020). CSR and Firm Reputation from Employee Perspective. Journal of Asian Finance, Economics and Business, 7(10), 171-182. W.Wahyuni. (2012). Kajian Teori Return Of Asset. http://eprints.uny.ac.id/8032/3/BAB 2-09409131016.pdf www.sahamok.com. (2017). Sektor BEI (Bursa Efek Indonesia) | Saham OK. https://www.sahamok.com/emiten/sektor-bei/ 